\title{
The Relationship between Gratitude, Wellbeing, Spirituality, and Experiencing Meaningful Work
}

\author{
Natasha M. Loi *(D) and Di Helen Ng \\ Faculty of Medicine and Health, School of Psychology, University of New England, \\ Armidale, NSW 2351, Australia; helencheng129@gmail.com \\ * Correspondence: nloi2@une.edu.au
}

Citation: Loi, N.M.; Ng, D.H. The Relationship between Gratitude, Wellbeing, Spirituality, and Experiencing Meaningful Work. Psych 2021, 3, 85-95. https://doi.org/ $10.3390 /$ psych3020009

Academic Editors: Mosad Zineldin and Nicola Magnavita

Received: 9 April 2021

Accepted: 14 May 2021

Published: 18 May 2021

Publisher's Note: MDPI stays neutral with regard to jurisdictional claims in published maps and institutional affiliations.

Copyright: (c) 2021 by the authors. Licensee MDPI, Basel, Switzerland. This article is an open access article distributed under the terms and conditions of the Creative Commons Attribution (CC BY) license (https:// creativecommons.org/licenses/by/ $4.0 /)$.

\begin{abstract}
Poor mental wellbeing not only affects an individual and their family, but it also affects the workplace and the society as a whole. Consequently, it is crucial to investigate approaches that can promote a positive mindset in order to enhance wellbeing. This study aimed to explore the association between gratitude, wellbeing, spirituality, and experiencing meaningful work. A sample of 197 participants (69.5\% female) completed measures of gratitude, experiencing meaningful work, spirituality, and several wellbeing indices. Gratitude was significantly positively associated with happiness, life satisfaction, flourishing, positive affect, spirituality, and experiencing meaningful work. A mediation analysis revealed that the relationship between wellbeing and experiencing meaningful work was partially mediated by gratitude. Additionally, spirituality did not moderate the relationship between gratitude and experiencing meaningful work. Overall, the findings indicate that fostering a grateful mindset could enhance wellbeing and work engagement, which in turn could lead to the experience of meaningful work.
\end{abstract}

Keywords: wellbeing; meaningful work; gratitude; spirituality

\section{Introduction}

The emergence of the positive psychology movement in the late twentieth century saw a new focus on understanding human behavior in order to promote individual wellbeing [1]. As part of this focus, research examined the connection of gratitude to other psychological, organizational, and personal constructs such as wellbeing, meaningful work, and spirituality [2-5]. Fredrickson's [6] broaden-and-build theory argues that positive emotions, such as gratitude, help build personal resources by broadening thinking and awareness. Indeed, previous studies have shown that gratitude enhances individuals' positive emotions and reduces negative emotions by broadening the individual's attention to the positive aspects of their lives [7]. For instance, Froh et al.'s [8] study, which focused on counting blessings, found that those who participated in the exercise experienced more positive affect, were more optimistic, and were more satisfied with life. Previous research has found that gratitude is associated with improved wellbeing, appears to build resilience, coping ability, prosocial behavior, and a healthy self-concept, and broadens positive perceptions of others or different circumstances (e.g., [9-12]).

McCullough et al. [13] conceptualized gratitude as a moral effect that functions not only as a response when someone is the beneficiary of prosocial behavior, but also motivates prosocial behavior from the recipient. How an act of beneficence is perceived or appraised by the recipient, therefore, plays a central role in the experience of gratitude, which leads to the formation of gratitude as the product of two information processing stages. The first stage involves the individual recognizing they have experienced a positive outcome and the second involves attributing these positive outcomes to another person [4]. A limitation of this conceptualization, though, is that it places gratitude in an interpersonal context and neglects other sources of gratitude [2]. For example, waking up early was regarded as a 
grateful event by respondents in a study conducted by Emmons and McCullough [14], indicating that gratitude does not always have to be directed at a benefactor.

Other researchers have conceptualized gratitude as a broad life orientation that makes an individual more sensitive to the positive aspects in life [12]. According to McCullough et al. [4], gratefulness can be viewed as an affective trait or disposition which decreases an individual's threshold for noticing acts of benevolence and responding with gratitude. People with a grateful disposition tend to experience more gratitude in terms of intensity, frequency, span, and density compared to less grateful individuals [4] which, in turn, could result in improved wellbeing.

Wellbeing involves experiencing an optimal quality of life, positive emotions, and general life satisfaction $[15,16]$. Subjective wellbeing (SWB), sometimes known as happiness in colloquial terms, includes what people feel and think [15]. SWB regards wellbeing from the perspective of attaining pleasure and avoiding pain [16]. Psychological wellbeing (PWB), on the other hand, refers to the degree of meaning, purpose, and satisfaction in a person's life [17]. PWB seeks to understand wellbeing from the perspective of selfactualization and how well an individual functions and flourishes. Although there is some overlap between these two approaches, there has been a push in recent years to develop a more holistic and integrated definition of wellbeing [7]. One example is the approach advocated by Seligman [1], which states that there are the following five elements of wellbeing: positive emotions, engagement, relationships, meaning, and achievements. The strength of Seligman's definition is that it considers the multidimensional nature of wellbeing. However, critics have claimed that this approach does not account for the contextual and conditional nature of people's lives [18].

The relationship between wellbeing and physical and psychological health is well established [19]. Ryff and Singer [20], for example, have found that PWB improves general health, including mitigating the cumulative effects of stress and improving the body's autoimmunity. Other studies have shown that wellbeing reduces the risk of depression [18] and improves the prognosis of certain diseases [21].

Throughout history, researchers, philosophers, and practitioners have theorized that gratitude fosters happiness. Studies have found that gratitude is linked to a range of positive emotions, such as contentment, happiness, and hope [14]. Additionally, grateful people tend to experience fewer negative emotions, including envy, depression, and resentment [14,22]. Gratitude, therefore, enhances SWB.

Gratitude has also been found to be positively related to PWB. For instance, Froh et al. [23] and Wood, Joseph, et al. [24] found that grateful people demonstrated greater life satisfaction. Wood et al. [25] also found that gratitude was positively associated with a range of psychological wellbeing variables, including environmental mastery, personal growth, purpose in life, and self-acceptance, which supports the idea that gratitude contributes to flourishing and a meaningful life.

Empirical research has also found a positive relationship between gratitude and health, particularly with regards to psychopathological conditions [4,26], including reduced stress and depression [27], and a reduced risk of developing anxiety disorders, alcohol and drug dependence, and bulimia nervosa [12]. Gratitude is also associated with improved outcomes in social functioning and positive relationships [28]. Grateful people tend to positively perceive the quality of their interpersonal relationships [27], are more willing to forgive and exhibit low narcissism [29,30], and report greater social support [23]. A grateful approach to life, therefore, broadens-and-builds a range of physical, emotional, psychological, and interpersonal benefits [11,14], which, in turn, could help to experience meaningful work.

Meaningful work refers to the sense of importance, value, worthwhileness, purpose, and usefulness that people attach to their work [31]. For an employee to experience meaningful work, they need to perceive that the job they do matches their values, beliefs, behavior, and self-concept [32,33]. Meaningful work also involves mutual respect, being 
appreciated and not taken for granted, as well as having positive relationships with colleagues and customers [34].

Previous research has found that meaningful work has been associated with greater job satisfaction, higher work engagement, and wellbeing (e.g., [35-38]). According to Rosso et al. [39], meaningful work is a significant component of wellbeing that can lead to a more satisfying and meaningful life. In a study conducted by Bakker [40], highly engaged workers were found to be happier and healthier than those less engaged. Other studies have revealed that meaningful work is also positively associated with positive affect [41], enthusiasm, a sense of contributing to the greater good, and a more positive work attitude [33,42]. One reason for this could be that when people view their jobs as meaningful, their work becomes valuable and an integral part of their lives $[43,44]$.

Studies suggest a link between gratitude and experiencing meaningful work. Howells [5] and Howells and Cumming [45], for example, found that gratitude could help improve relationships between staff members. Additionally, Chan [46] found that gratitude was positively associated with personal achievement and negatively correlated with burnout.

At present, there is limited research into gratitude as a mediator in the relationship between wellbeing and experiencing meaningful work. Some researchers have hypothesized that gratitude offers a pathway to enhance work engagement, which in turn leads to the experience of meaningful work [12]. Since gratitude has been found to be associated with higher levels of positive affect and satisfaction in life [8,47], improved relationship functioning, the inclination to reciprocate grateful actions $[10,28]$, lower levels of resentment [14], greater resilience, improved coping skills, and an optimistic perspective $[11,14,45,48]$, it is possible these effects of gratitude may mediate the relationship between wellbeing and experiencing meaningful work.

Spirituality can be defined in terms of either an extrinsic public observable religious or spiritual practice, such as attending church activities, or an intrinsic private relationship with a divine and spiritual transcendence, whereby an individual enhances their life through spiritual teaching, prayer, and building a close relationship with the divine $[3,49,50]$. Emmons and Kneezel [3] found that measures of extrinsic and intrinsic spirituality significantly correlated with an increased frequency of thankful feelings experienced per day. People who were more spiritually inclined were more disposed towards recognizing the positive aspects of life than less spiritual individuals. Emmons and Kneezel [3] also found that spiritual people were more likely to believe that everything in life has a purpose, a perspective that may foster gratefulness because it helps people notice and appreciate the opportunities life has to offer. Appreciating the interconnectedness of life also gives people a sense of commitment and responsibility towards others which, in turn, may lead to increased gratefulness [3].

Research has attempted to explain the relationship between gratitude and spirituality. Smith et al. [51] propose that gratitude is a positive mood characteristic of spiritually inclined people. This claim has found support from several sources. First, several religions view gratitude as a noble virtue that followers are encouraged to develop [2]. An examination of the texts, prayers, and teachings of Judaism, Christianity, and Islam, for example, reveal gratitude as a recurring theme. Second, research has found that instead of interpreting positive events as intentional human effort, spiritual people tend to attribute positive events and outcomes as intentional benevolent acts from God which, in turn, engenders gratitude as a response [2]. In contrast, less spiritual individuals tend to view such events as coincidental. Spiritual people thus tend to exhibit higher gratitude levels compared to people who are not spiritual [3]. The converse may hold true as well. It is possible that a grateful disposition helps people to be more aware of the transcendent forces that contribute to their wellbeing, which leads them to be more spiritually inclined [3].

Research also suggests that participation in organized religion enhances gratitude by improving social support. For example, many churches have a range of meetings that help facilitate social bonding and spiritual encouragement. Research shows that the spiritual 
support received from other church members may enhance wellbeing, and this sense of relational intimacy may engender feelings of gratitude [52,53]. This is supported by studies demonstrating that people who attend church tend to have more supportive relationships which, in turn, has been shown to be positively related to gratitude [54].

Studies have also shown that religious or spiritual people are at a lower risk of developing depressive symptoms and other mental health disorders $[3,55,56]$. One possible explanation is that spirituality encourages a positive appraisal of life which, in turn, engenders positive emotions like hope, love, forgiveness, gratitude, and optimism [51,57]. This was supported by Krause's [58] study, which examined whether the feeling of gratitude reduced the effects of stress on health during the later years of life. The results showed that the impact of stress was lower in those older people who were more grateful to God. Laird et al. [59] found an association between thanksgiving prayers and SWB in a sample of arthritis patients. Thus, these studies suggest there is a link between spirituality and gratitude, and between spirituality and wellbeing. Therefore, spirituality may play a moderating role in the relationship between gratitude and wellbeing by influencing how we appraise life circumstances, how we relate to others, and how we cope with stressful situations. In particular, it may play an essential role in how people approach and experience their work.

A large number of studies have examined the associations between gratitude, wellbeing and meaningful work (e.g., [5,10,12,14]). In addition, there exists a considerable body of research on the link between spirituality and gratitude (e.g., [3,58]). While there is evidence to suggest that gratitude can result in positive outcomes on a range of wellbeing indices, such as happiness, positive emotions, life satisfaction, purpose in life (i.e., flourishing), resilience to stress, and social support (e.g., [23-25]), less research has examined the mediating role of gratitude in the relationship between wellbeing and experiencing meaningful work.

The purpose of the present study, therefore, was to examine the mediating role of gratitude between various subjective and psychological wellbeing indices (i.e., happiness, life satisfaction, flourishing, and positive affect), and experiencing meaningful work as well as to examine the role that spirituality has on gratitude and experiencing meaningful work. It was therefore hypothesized that gratitude would be positively associated with the various wellbeing indices, spirituality, and experiencing meaningful work. Secondly, it was hypothesized that gratitude would mediate the relationship between various positive wellbeing indices (i.e., happiness, life satisfaction, flourishing, and positive affect), and experiencing meaningful work. Finally, it was hypothesized that spirituality would moderate the relationship between gratitude and experiencing meaningful work.

\section{Materials and Methods}

\subsection{Participants}

An a priori power analysis using $G^{*}$ Power 3.1 [60] found that 123 participants would be required, assuming a medium effect size $\left(\mathrm{f}^{2}=0.15\right)$, an alpha of 0.05 , and target power of 0.90 . A total of 197 people subsequently participated in the present study. The sample comprised 59 males (29.9\%), 137 females $(69.5 \%)$, and 1 who identified as other aged between 18 and 74 years of age $(M=36.48, S D=10.97)$. The majority of participants identified as Australian $(69 \% ; n=136)$. Of this sample, 48.7 per cent $(n=96)$ reported being employed full-time, 23.9 per cent $(n=47)$ indicated part-time employment, 19.3 per cent $(n=38)$ were employed casually, and 8.1 per cent $(n=16)$ were self-employed. The majority of participants reported being married $(57.9 \% ; n=114)$. Amongst the majority of participants, 36.5 per cent $(n=72)$ reported being Christian and 49.7 per cent $(n=98)$ reported no religion.

\subsection{Materials}

Demographics. Participants were asked to provide information pertaining to their gender, age, nationality, relationship status, religion affiliation, and employment status. 
Gratitude. The Gratitude Questionnaire six item form ([4]) was used to assess the experience of gratitude. Each item was rated on a 7-point Likert-type rating scale ( 1 = strongly disagree; 7 = strongly agree), with high scores indicating greater dispositional gratitude. The scale demonstrated good internal consistency with the current sample $(\alpha=0.84)$.

Happiness. The 29-item Oxford Happiness Scale (OHS; [61]) was used to assess happiness. Each item was rated on a 6-point Likert-type rating scale $(1=$ strongly disagree; 6 = strongly agree), with high scores indicating a greater level of happiness. The OHS demonstrated excellent internal consistency with this sample $(\alpha=0.93)$.

Life Satisfaction. The 5-item Satisfaction With Life Scale (SWLS; [62]) assesses the perceptive component of hedonic wellbeing. Each item is rated on a 7-point Likert-type scale $(1=$ strongly disagree; $7=$ strongly agree $)$ with high scores indicating greater satisfaction with life. The SWLS showed good internal consistency with the current sample ( $\alpha=0.87)$.

Flourishing. The 8-item Flourishing Scale ([63]) was used to measure the attainment of prosperity in areas including feelings of competence, positive relationships, and purpose in life (e.g., "I lead a purposeful and meaningful life"). Each item is rated on a 7-point Likert-type scale ( 1 = strongly disagree; 7 = strongly agree) with high scores indicating positive self-perceived psychological and social strength. The scale demonstrated excellent internal consistency with the current sample $(\alpha=0.92)$.

Positive Affect. The Positive and Negative Affect Schedule (PANAS; [64]) was used to measure the affective component of wellbeing. The PANAS consists of two 10-item subscales assessing the tendency to experience positive and negative emotions. Each item is rated on a 5-point Likert-type rating scale $(1=$ not at all; $5=$ extremely $)$, with high scores indicating greater positive (PA) or negative affect. Only the PA subscale was used in this study. The scale showed good internal consistency with the current sample $(\alpha=0.86)$.

Experiencing Meaningful Work. The Work and Meaning Inventory (WAMI; [65]) was used to assess positive meaning, meaning-making through work, and greater good motivations. The WAMI consists of 10 items across the three dimensions. Each item is rated on a 7 -point Likert-type rating scale $(1=$ strongly disagree; $7=$ strongly agree $)$, with high scores representing greater levels of perceived meaningful work. The scale exhibited high internal consistency $(\alpha=0.90)$.

Spirituality. The 13-item spiritual support subscale of Genia's [66] Spiritual Experience Index-Revised was used to measure spirituality. Each item is rated on a 6-point Likert-type scale ( 1 = strongly disagree; 6 = strongly agree $)$, with a high score suggesting a mature faith. The subscale demonstrated excellent internal consistency with the current sample $(\alpha=0.95)$.

\subsection{Procedure}

Ethics approval was acquired through the host university's human research ethics committee before initiating the research. Following approval, the online survey was made available via the Qualtrics ${ }^{\mathrm{TM}}$ (Provo, UT, USA) secure site. Participants were recruited via social media, email, and the university's first-year psychology course pool. Each participant was required to peruse the information sheet, before providing consent to participate in the study. Participants were advised of their right to withdraw from the study at any time without consequence and without needing to provide an explanation. After providing consent, participants completed the demographic questions followed by the seven questionnaires. The survey took approximately $20 \mathrm{~min}$ to complete. First-year psychology students were offered credit for participation.

\section{Results}

\subsection{Statistical Analysis}

IBM SPSS version 25 (Amarok, NY, USA) was used to carry out all analyses. To examine the relationship between study variables, a Pearson correlation analysis was 
conducted. Mediation and moderation analyses were conducted with Hayes' PROCESS macro for SPSS [67].

\subsection{Pearson Correlation Analysis}

Results of the Pearson correlation can be found in Table 1. The hypothesis that gratitude would be positively associated with the various wellbeing indices, spirituality, and experiencing meaningful work was supported.

Table 1. Pearson correlation matrix among main study variables.

\begin{tabular}{ccccccc}
\hline Variable & $\mathbf{1}$ & $\mathbf{2}$ & $\mathbf{3}$ & $\mathbf{4}$ & $\mathbf{5}$ & $\mathbf{6}$ \\
\hline 1. Gratitude & - & & & & & \\
2. Happiness & $0.55^{* * *}$ & - & & & & \\
3. Life satisfaction & $0.49^{* * *}$ & $0.70^{* * *}$ & - & & & \\
4. Flourishing & $0.59^{* * *}$ & $0.76^{* * *}$ & $0.72^{* * *}$ & - & & \\
5. Positive affect & $0.45^{* * *}$ & $0.73^{* * *}$ & $0.58^{* * *}$ & $0.64^{* * *}$ & - & - \\
6. Meaningful work & $0.34^{* *}$ & $0.41^{* * *}$ & $0.32^{* * *}$ & $0.49^{* * *}$ & $0.41^{* * *}$ & - \\
7. Spirituality & $0.21^{* *}$ & $0.17^{*}$ & $0.22^{* *}$ & $0.15^{*}$ & $0.17^{*}$ & $0.26^{* * *}$ \\
\hline Note. $^{* * *} p<0.001^{* *} p<0.01^{*} p<0.05$ & & & & & &
\end{tabular}

\subsection{Mediation Analyses}

To test the hypothesis that gratitude would mediate the relationship between various wellbeing indices and experiencing meaningful work, a composite index of wellbeing was created. $Z$ scores for happiness, satisfaction with life, flourishing, and positive affect were calculated. A principal axis factor analysis with direct oblimin rotation was then conducted to explore the factor structure of these measures. The Kaiser-Meyer-Olkin measure of sampling adequacy was 0.82 , indicating that the strength of the relationships among the variables was high. The analysis extracted a single factor, explaining 76.76 per cent of the variance in the data. All factor loadings ranged between 0.84 (PA) and 0.92 (happiness). Aggregate wellbeing was computed by summing the $z$ score for the four wellbeing measures $(\alpha=0.90)$.

As shown in Figure 1, aggregate wellbeing was a significant predictor of experiencing meaningful work and gratitude (both $p$ s $<0.001$ ). Gratitude, however, did not significantly predict experiencing meaningful work $(p=0.357)$. The results support the hypothesis that gratitude mediates the relationship between aggregate wellbeing and experiencing meaningful work.

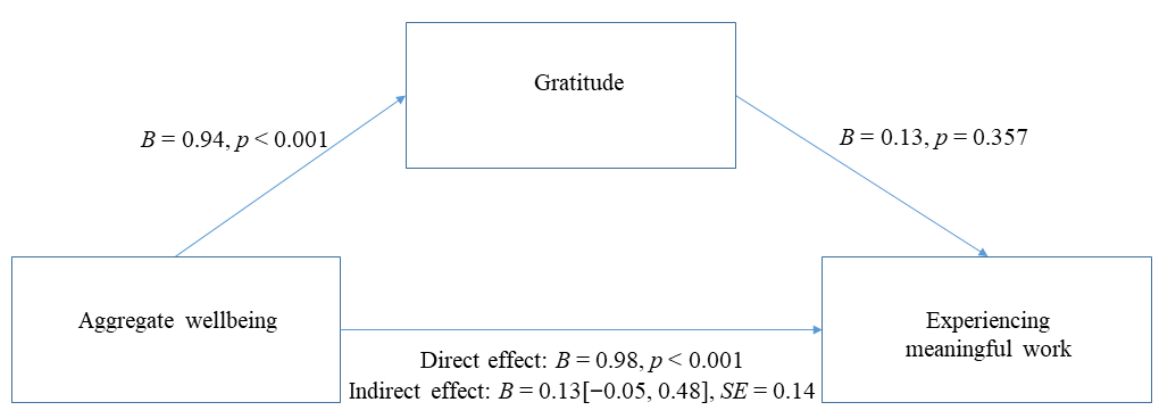

Figure 1. The mediating role of gratitude between aggregate wellbeing and experiencing meaningful work. $B=$ unstandardized beta coefficient; $S E=$ standard error.

\subsection{Moderation Analysis}

A multiple regression moderation analysis was conducted using the Hayes PROCESS macro model 1 to assess whether spirituality moderated the relationship between gratitude and experiencing meaningful work. Gratitude and spirituality accounted for a significant amount of variance in experiencing meaningful work, $R^{2}=0.15, F(3,193)=5.99$, 
$p=0.001$. However, the interaction between gratitude and spirituality was not significant, $b=-0.01[-0.02,0.01], S E=0.01, p=0.424$.

\section{Discussion}

The aim of the current study was to examine the mediating role of gratitude in the relationship between various measures of subjective and psychological wellbeing, and experiencing meaningful work. In addition, this study also examined the role of spirituality in the relationship between gratitude and the experience of meaningful work. The first hypothesis that gratitude would be positively associated with happiness, life satisfaction, flourishing, positive affect, spirituality, and experiencing meaningful work and negatively associated with negative affect was supported. The findings are consistent with previous research reporting gratitude's relationship with multiple indices of wellbeing, including positive affect, happiness, hope, and life satisfaction, as well as highlighting a range of beneficial outcomes including optimism, forgiveness, flourishing, fulfilment, and increased productivity $[8,14,68]$. Thus, this study underpins the importance of gratitude as a disposition that can be developed and enhanced so as to promote these kinds of positive outcomes.

The second hypothesis that gratitude would mediate the relationship between various wellbeing indices and experiencing meaningful work was supported. Previous research has consistently shown that gratitude practice results in positive emotions and a high level of satisfaction with life [47]. Based on Fredrickson's [6] broaden-and-build theory, it is possible that gratitude enhances work engagement and enables individuals to experience meaningful work by building their work-related and personal resources [69]. For example, gratitude has been shown to broaden-and-build positive emotions, improve interpersonal relationships, and reduce levels of resentment which, in turn, could foster a co-operative and supportive organizational environment $[5,14,45,70]$. In addition, feelings of gratitude may foster a positive working environment, enhance learning and growth [71], heighten cognitive performance, increase resilience, improve coping skills, decrease the risk of exhaustion, and increase trust and commitment to the organization [11,46,48,69,72].

The current study also hypothesized that spirituality would play a moderating role in the relationship between gratitude and experiencing meaningful work. The results, however, did not support this hypothesis. While gratitude and spirituality both accounted for a significant amount of the variance in experiencing meaningful work, the interaction between gratitude and spirituality was not significant. While spirituality may foster or be associated with gratitude, this does not mean that gratitude must be understood only within a spiritual or religious context $[3,50]$. It is possible that the positive relationship between gratitude and spirituality is a reciprocal one-that those with spiritual worldviews tend to acknowledge the kindness of a benevolent agent (such as God) and are subsequently more grateful as a result (e.g., [3]). Alternatively, those with a grateful disposition, may be more open to all the possibilities that life has to offer, whether that be belief in a power greater than themselves, or the ability to experience meaning in their day-to-day activities including at work.

\subsection{Implications}

The individual, social, and health implications of gratitude on wellbeing are extensive and beneficial. The findings of the present study have indicated that gratitude can not only promote wellbeing, but may also ultimately transform the workplace. Increasing gratitude may be a potentially promising intervention that can enhance greater wellbeing, mend broken relationships, increase productivity and job satisfaction, and buffer psychological and social distress which could, in turn, reduce depression, suicidal risk, and healthcare costs (e.g., $[27,73,74])$. Gratitude may be one pathway to experience meaningful work, resulting in a more meaningful life [39]. 


\subsection{Limitations and Future Directions}

A number of limitations are present in the current study. First, respondents were not necessarily representative of the general population but rather a convenience sample with an over-representation of females, which could limit the generalizability of the findings. Additionally, the use of a convenience sample may result in an inability to generalize the findings more broadly. However, the mean age of our sample (36.48 years) was certainly representative of the working population at large. Furthermore, while the oldest participant in our sample was 74 years, even this does not necessarily impede the generalizability of our findings. As the majority of our sample was based in Australia (69\%), recent research by the Australian Institute of Health and Welfare [75] has found that Australians over the age of 65 years have a workforce participation rate of $13 \%$. Given that all participants in our study indicated that they were currently employed, our sample may be regarded as representative of people in the (Australian) workforce more broadly. Second, this study relied solely upon self-report data of the level to which people appraise gratitude, happiness, life satisfaction, flourishing, positive affect, spirituality and experiencing meaningful work. There is the potential for distortion in the responses due to response or social desirability bias [76]. A further limitation may exist with respect to the relationship between spirituality and gratitude. The current study examined general attitudes toward dispositional gratitude and not attitudes regarding gratitude towards a specific event. It is possible the association between spirituality and gratitude may alter if the reaction of gratitude towards a specific event is examined.

The impact of gratitude on wellbeing and experiencing meaningful work is worthy of further robust and longitudinal investigation. Future research in this area may help to explore any barriers to gratitude, and therefore may provide insight into the design of a gratitude intervention targeting specific groups in order to enhance greater wellbeing. This will complement the research that has found that gratitude at work is related to, among other positive outcomes, improved job satisfaction (e.g., [77]), reduced burnout (e.g., [78]), and increased organizational citizenship behaviours (e.g., [79]).

A more extensive study could be done to examine methods for fostering gratitude in people, organizations, and society, and to explore how broadening-and-building a grateful mindset can play a significant role in enhancing overall wellbeing and experiencing meaningful work.

\section{Conclusions}

Studying how gratitude is related to wellbeing, experiencing meaningful work, and spirituality can potentially reap benefits for the individual, the organization, and society as it may help researchers understand possible pathways to broadening-and-building individuals' personal, psychological, and spiritual resources. The insight gained in this study may also help to explore practical ways of reducing the burden of psychological suffering and loss of productivity.

This study aimed to explore the relationship between gratitude, wellbeing, spirituality, and experiencing meaningful work. The results found positive relationships between gratitude and wellbeing, and spirituality and experiencing meaningful work, which was consistent with previous findings. The study also found that gratitude was a mediating path in the relationship between wellbeing and experiencing meaningful work. Hence, fostering gratitude should be encouraged in the workplace and alongside existing clinical therapies.

Author Contributions: Conceptualization, N.M.L. and D.H.N.; methodology, D.H.N.; formal analysis, N.M.L.; writing — original draft preparation, N.M.L. and D.H.N.; writing-review and editing, N.M.L. All authors have read and agreed to the published version of the manuscript.

Funding: This research received no external funding.

Institutional Review Board Statement: The study was conducted according to the guidelines of the Declaration of Helsinki, and approved by the Human Research Ethics Committee of the University of New England, Australia (authority number HE18-122, valid to 17 May 2019). 
Informed Consent Statement: Informed consent was obtained from all subjects involved in the study.

Data Availability Statement: The data presented in this study are available on request from the corresponding author.

Conflicts of Interest: The authors declare no conflict of interest.

\section{References}

1. Seligman, M.E.P. Flourish; Free Press: New York, NY, USA, 2011.

2. Emmons, R.A.; Crumpler, C.A. Gratitude as a Human Strength: Appraising the Evidence. J. Soc. Clin. Psychol. 2000, 19, 56-69. [CrossRef]

3. Emmons, R.A.; Kneezel, T.T. Giving thanks: Spiritual and religious correlates of gratitude. J. Psychol. Christ. 2005, $24,140-148$.

4. McCullough, M.E.; Emmons, R.A.; Tsang, J.-A. The grateful disposition: A conceptual and empirical topography. J. Pers. Soc. Psychol. 2002, 82, 112-127. [CrossRef]

5. Howells, K. An exploration of the role of gratitude in enhancing teacher-student relationships. Teach. Teach. Educ. 2014, 42, 58-67. [CrossRef]

6. Fredrickson, B.L. The role of positive emotions in positive psychology: The broaden-and-build theory of positive emotions. Am. Psychol. 2001, 56, 218-226. [CrossRef] [PubMed]

7. Odou, N.; Vella-Brodrick, D.A. The Efficacy of Positive Psychology Interventions to Increase Well-Being and the Role of Mental Imagery Ability. Soc. Indic. Res. 2011, 110, 111-129. [CrossRef]

8. Froh, J.J.; Sefick, W.J.; Emmons, R.A. Counting blessings in early adolescents: An experimental study of gratitude and subjective well-being. J. Sch. Psychol. 2008, 46, 213-233. [CrossRef]

9. Adler, M.G.; Fagley, N.S. Appreciation: Individual Differences in Finding Value and Meaning as a Unique Predictor of Subjective Well-Being. J. Pers. 2005, 73, 79-114. [CrossRef]

10. Algoe, S.B.; Haidt, J. Witnessing excellence in action: The 'other-praising' emotions of elevation, gratitude, and admiration. $J$. Posit. Psychol. 2009, 4, 105-127. [CrossRef]

11. Fredrickson, B.L. Gratitude, like other positive emotions, broadens and builds. In The Psychology of Gratitude; Emmons, R.A., McCullough, M.E., Eds.; Oxford University Press: New York, NY, USA, 2004; pp. 145-166.

12. Wood, A.M.; Froh, J.J.; Geraghty, A.W. Gratitude and well-being: A review and theoretical integration. Clin. Psychol. Rev. 2010, 30, 890-905. [CrossRef]

13. McCullough, M.E.; Kilpatrick, S.D.; Emmons, R.A.; Larson, D.B. Is gratitude a moral affect? Psychol. Bull. 2001, 127, 249-266. [CrossRef]

14. Emmons, R.A.; McCullough, M.E. Counting blessings versus burdens: An experimental investigation of gratitude and subjective well-being in daily life. J. Pers. Soc. Psychol. 2003, 84, 377-389. [CrossRef] [PubMed]

15. Diener, E. Subjective well-being: The science of happiness and a proposal for a national index. Am. Psychol. 2000, 55, 34-43. [CrossRef]

16. Ryan, R.M.; Deci, E.L. On Happiness and Human Potentials: A Review of Research on Hedonic and Eudaimonic Well-Being. Annu. Rev. Psychol. 2001, 52, 141-166. [CrossRef] [PubMed]

17. Ryff, C.D.; Keyes, C.L.M. The structure of psychological well-being revisited. J. Pers. Soc. Psychol. 1995, 69, 719-727. [CrossRef]

18. Wood, A.M.; Joseph, S. The absence of positive psychological (eudemonic) well-being as a risk factor for depression: A ten year cohort study. J. Affect. Disord. 2010, 122, 213-217. [CrossRef] [PubMed]

19. Diener, E.; Chan, M.Y. Happy People Live Longer: Subjective Well-Being Contributes to Health and Longevity. Appl. Psychol. Health Well-Being 2011, 3, 1-43. [CrossRef]

20. Ryff, C.D.; Singer, B. Interpersonal Flourishing: A Positive Health Agenda for the New Millennium. Pers. Soc. Psychol. Rev. 2000, 4, 30-44. [CrossRef]

21. Lamers, S.M.A.; Bolier, L.; Westerhof, G.J.; Smit, F.; Bohlmeijer, E.T. The impact of emotional well-being on long-term recovery and survival in physical illness: A meta-analysis. J. Behav. Med. 2012, 35, 538-547. [CrossRef]

22. Froh, J.J.; Emmons, R.A.; Card, N.A.; Bono, G.; Wilson, J.A. Gratitude and the Reduced Costs of Materialism in Adolescents. J. Happiness Stud. 2011, 12, 289-302. [CrossRef]

23. Froh, J.J.; Kashdan, T.B.; Ozimkowski, K.M.; Miller, N. Who benefits the most from a gratitude intervention in children and adolescents? Examining positive affect as a moderator. J. Posit. Psychol. 2009, 4, 408-422. [CrossRef]

24. Wood, A.M.; Joseph, S.; Maltby, J. Gratitude uniquely predicts satisfaction with life: Incremental validity above the domains and facets of the five factor model. Pers. Individ. Differ. 2008, 45, 49-54. [CrossRef]

25. Wood, A.M.; Joseph, S.; Maltby, J. Gratitude predicts psychological well-being above the Big Five facets. Pers. Individ. Differ. 2009, 46, 443-447. [CrossRef]

26. Watkins, P.C.; Woodward, K.; Stone, T.; Kolts, R.L. Gratitude and Happiness: Development of a Measure of Gratitude, and Relationships with Subjective Well-Being. Soc. Behav. Pers. Int. J. 2003, 31, 431-451. [CrossRef]

27. Wood, A.M.; Maltby, J.; Gillett, R.; Linley, P.A.; Joseph, S. The role of gratitude in the development of social support, stress, and depression: Two longitudinal studies. J. Res. Pers. 2008, 42, 854-871. [CrossRef] 
28. Algoe, S.B.; Haidt, J.; Gable, S.L. Beyond reciprocity: Gratitude and relationships in everyday life. Emotion 2008, 8, 425-429. [CrossRef]

29. DeShea, L. A scenario-based scale of willingness to forgive. Individ Differ. Res. 2003, 1, 201-217.

30. Farwell, L.; Wohlwend-Lloyd, R. Narcissistic Processes: Optimistic Expectations, Favorable Self-Evaluations, and Self-Enhancing Attributions. J. Pers. 1998, 66, 65-83. [CrossRef]

31. Kahn, W.A. Psychological Conditions of Personal engagement and disengagement at work. Acad. Manag. J. 1990, 33, 692-724. [CrossRef]

32. Ghadi, M.Y.; Fernando, M.; Caputi, P. Describing work as meaningful: Towards a conceptual clarification. J. Organ. Eff. People Perform. 2015, 2, 202-223. [CrossRef]

33. Steger, M.; Dik, B.J. Work as meaning: Individual and organizational benefits of engaging in meaningful work. In Oxford Handbook of Positive Psychology and Work; Linley, P.A., Harrington, S., Garcea, N., Eds.; Oxford University Press: Oxford, UK, 2010; pp. 131-142.

34. Albrecht, S.L. Work engagement and the positive power of meaningful work. In Advances in Positive Organizational Psychology; Bakker, A.B., Ed.; Emerald Group Publishing: Bingley, UK, 2013; pp. 237-260.

35. Fouché, E.; Rothmann, S.; Van Der Vyver, C. Antecedents and outcomes of meaningful work among school teachers. SA J. Ind. Psychol. 2017, 43, 1398. [CrossRef]

36. Soane, E.; Shantz, A.; Alfes, K.; Truss, C.; Rees, C.; Gatenby, M. The Association of Meaningfulness, Well-Being, and Engagement with Absenteeism: A Moderated Mediation Model. Hum. Resour. Manag. 2013, 52, 441-456. [CrossRef]

37. Orkibi, H.; Bar Nir, A. Linking collective self-esteem to well-being indicators of arts therapies students and practitioners: Meaning and engagement as mediators. Arts Psychother. 2015, 45, 26-35. [CrossRef]

38. Magnano, P.; Santisi, G.; Zammitti, A.; Zarbo, R.; Di Nuovo, S. Self-Perceived Employability and Meaningful Work: The Mediating Role of Courage on Quality of Life. Sustainability 2019, 11, 764. [CrossRef]

39. Rosso, B.D.; Dekas, K.H.; Wrzesniewski, A. On the meaning of work: A theoretical integration and review. Res. Organ. Behav. 2010, 30, 91-127. [CrossRef]

40. Bakker, A.B. Building engagement in the workplace. In The Peak Performing Organization; Burke, R.J., Cooper, C.L., Eds.; Routledge: Abingdon, UK, 2009; pp. 50-72.

41. King, L.A.; Hicks, J.A.; Krull, J.L.; Del Gaiso, A.K. Positive affect and the experience of meaning in life. J. Pers. Soc. Psychol. 2006, 90, 179-196. [CrossRef]

42. Hall, D.T.; Chandler, D.E. Psychological success: When the career is a calling. J. Organ. Behav. 2005, 26, 155-176. [CrossRef]

43. Duffy, R.D.; Dik, B.J.; Steger, M.F. Calling and work-related outcomes: Career commitment as a mediator. J. Vocat. Behav. 2011, 78, 210-218. [CrossRef]

44. Willemse, M.; Deacon, E. Experiencing a sense of calling: The influence of meaningful work on teachers' work attitudes. SA J. Ind. Psychol. 2015, 41. [CrossRef]

45. Howells, K.; Cumming, J. Exploring the role of gratitude in the professional experience of pre-service teachers. Teach. Educ. 2012, 23, 71-88. [CrossRef]

46. Chan, D.W. Gratitude, gratitude intervention and subjective well-being among Chinese school teachers in Hong Kong. Educ. Psychol. 2010, 30, 139-153. [CrossRef]

47. Polak, E.L.; McCullough, M.E. Is gratitude an alternative to materialism? J. Happiness Stud. 2006, 7, 343-360. [CrossRef]

48. Wood, A.M.; Joseph, S.; Linley, P.A. Coping Style as a Psychological Resource of Grateful People. J. Soc. Clin. Psychol. 2007, 26, 1076-1093. [CrossRef]

49. Lambert, N.M.; Fincham, F.D.; Braithwaite, S.R.; Graham, S.M.; Beach, S.R.H. Can prayer increase gratitude? Psychol. Relig. Spirit. 2009, 1, 139-149. [CrossRef]

50. Tsang, J.-A.; Schulwitz, A.; Carlisle, R.D. An experimental test of the relationship between religion and gratitude. Psychol. Relig. Spirit. 2012, 4, 40-55. [CrossRef]

51. Smith, T.B.; McCullough, M.E.; Poll, J. Religiousness and depression: Evidence for a main effect and the moderating influence of stressful life events. Psychol. Bull. 2003, 129, 614-636. [CrossRef]

52. Krause, N.; Ellison, C.G. Social environment of the church and feelings of gratitude toward god. Psychol. Relig. Spirit. 2009, 1, 191-205. [CrossRef]

53. Krause, N.; Hayward, R.D. Church-based social support, functional disability, and change in personal control over time. J. Relig. Health 2013, 53, 267-278. [CrossRef] [PubMed]

54. Kraus, R.; Desmond, S.A.; Palmer, Z.D. Being Thankful: Examining the Relationship between Young Adult Religiosity and Gratitude. J. Relig. Health 2014, 54, 1331-1344. [CrossRef]

55. Krause, N. Religious Involvement, Gratitude, and Change in Depressive Symptoms over Time. Int. J. Psychol. Relig. 2009, 19, 155-172. [CrossRef]

56. Magnano, P.; Zammitti, A.; Dibilio, R.; Faraci, P. Italian validation of the Jarel Spiritual Well-Being Scale. Ment. Health Relig. Cult. 2019, 22, 626-644. [CrossRef]

57. Levin, J. A Prolegomenon to an Epidemiology of Love: Theory, Measurement, and Health Outcomes. J. Soc. Clin. Psychol. 2000, 19, 117-136. [CrossRef]

58. Krause, N. Gratitude toward God, Stress, and Health in Late Life. Res. Aging 2006, 28, 163-183. [CrossRef] 
59. Laird, S.P.; Snyder, C.R.; Rapoff, M.A.; Green, S. RESEARCH: “Measuring Private Prayer: Development, Validation, and Clinical Application of the Multidimensional Prayer Inventory". Int. J. Psychol. Relig. 2004, 14, 251-272. [CrossRef]

60. Faul, F.; Erdfelder, E.; Buchner, A.; Lang, A.-G. Statistical power analyses using G*Power 3.1: Tests for correlation and regression analyses. Behav. Res. Methods 2009, 41, 1149-1160. [CrossRef] [PubMed]

61. Hills, P.; Argyle, M. The Oxford Happiness Questionnaire: A compact scale for the measurement of psychological well-being. Pers. Individ. Differ. 2002, 33, 1073-1082. [CrossRef]

62. Diener, E.; Emmons, R.A.; Larsen, R.J.; Griffin, S. The Satisfaction with Life Scale. J. Pers. Assess. 1985, 49, 71-75. [CrossRef] [PubMed]

63. Diener, E.; Wirtz, D.; Tov, W.; Kim-Prieto, C.; Choi, D.-W.; Oishi, S.; Biswas-Diener, R. New Well-being Measures: Short Scales to Assess Flourishing and Positive and Negative Feelings. Soc. Indic. Res. 2010, 97, 143-156. [CrossRef]

64. Watson, D.; Clark, L.A.; Tellegen, A. Development and validation of brief measures of positive and negative affect: The PANAS scales. J. Pers. Soc. Psychol. 1988, 54, 1063-1070. [CrossRef]

65. Steger, M.F.; Dik, B.J.; Duffy, R.D. Measuring Meaningful Work. J. Career Assess. 2012, 20, 322-337. [CrossRef]

66. Genia, V. The Spiritual Experience Index: Revision and Reformulation. Rev. Relig. Res. 1997, 38, 344. [CrossRef]

67. Hayes, A.F. Introduction to Mediation, Moderation, and Conditional Process Analysis: A Regression-Based Approach, 2nd ed.; Guilford Press: New York, NY, USA, 2018.

68. Kaplan, J. Gratitude survey conducted for the John Templeton Foundation June-October 2012. Available online: https:// greatergood.berkeley.edu/images/uploads/JTF_GRATITUDE_REPORTpub.doc (accessed on 9 January 2020).

69. Wandell, J. A proposed pilot study of a gratitude practice program to increase gratitude among educators: The first step towards exploring the potential of gratitude practice to increase work engagement and buffer against and decrease burnout. Int. J. Child. Youth Fam. Stud. 2016, 7, 275. [CrossRef]

70. Sekerka, L.E.; Vacharkulksemsuk, T.; Fredrickson, B.L. Positive emotions: Broadening and building upward spirals of sustainable enterprise. In The Oxford Handbook of Positive Organizational Scholarship; Cameron, K.S., Speitzer, G.M., Eds.; Oxford University Press: New York, NY, USA, 2012; pp. 168-177.

71. Venkataramani, V.; Dalal, R.S. Who helps and harms whom? Relational antecedents of interpersonal helping and harming in organizations. J. Appl. Psychol. 2007, 92, 952-966. [CrossRef]

72. Ferrin, D.L.; Bligh, M.C.; Kohles, J.C. It takes two to tango: An interdependence analysis of the spiraling of perceived trustworthiness and cooperation in interpersonal and intergroup relationships. Organ. Behav. Hum. Decis. Process. 2008, 107, 161-178. [CrossRef]

73. Rash, J.A.; Matsuba, M.K.; Prkachin, K.M. Gratitude and Well-Being: Who Benefits the Most from a Gratitude Intervention? Appl. Psychol. Health Well-Being 2011, 3, 350-369. [CrossRef]

74. Waters, L. Predicting Job Satisfaction: Contributions of Individual Gratitude and Institutionalized Gratitude. Psychology 2012, 03, 1174-1176. [CrossRef]

75. Australian Institute of Health and Welfare. Older Australia at a Glance. Available online: https://www.aihw.gov.au/ reports/older-people/older-australia-at-a-glance/contents/social-and-economic-engagement/employment-and-economicparticipation (accessed on 12 May 2021).

76. Meltzoff, J.; Cooper, H. Critical Thinking about Research: Psychology and Related Fields; American Psychological Association (APA): Washington, DC, USA, 2018.

77. Stegen, A.; Wankier, J. Generating Gratitude in the Workplace to Improve Faculty Job Satisfaction. J. Nurs. Educ. 2018, 57, 375-378. [CrossRef]

78. Lanham, M.; Rye, M.; Rimsky, L.; Weill, S. How Gratitude Relates to Burnout and Job Satisfaction in Mental Health Professionals. J. Ment. Health Couns. 2012, 34, 341-354. [CrossRef]

79. Guzzo, R.F.; Wang, X.; Abbott, J. Corporate Social Responsibility and Individual Outcomes: The Mediating Role of Gratitude and Compassion at Work. Cornell Hosp. Q. 2020. [CrossRef] 